\title{
Oxygen and Carbon Isotope Composition in Primary Carbonatites of the World: Data Summary and Linear Trends
}

\author{
Alexander V. Bolonin \\ Central Geological Research Institute for Nonferrous and Precious Metals (TSNIGRI), Moscow, Russia \\ Email: bolonin.a@inbox.ru
}

How to cite this paper: Bolonin, A.V. (2019) Oxygen and Carbon Isotope Composition in Primary Carbonatites of the World: Data Summary and Linear Trends. Open Journal of Geology, 9, 424-439. https://doi.org/10.4236/ojg.2019.98028

Received: July 10, 2019

Accepted: August 20, 2019

Published: August 23, 2019

Copyright ( 2019 by author(s) and Scientific Research Publishing Inc. This work is licensed under the Creative Commons Attribution International License (CC BY 4.0).

http://creativecommons.org/licenses/by/4.0/

\section{Open Access}

\begin{abstract}
The article contains the results of statistical processing of a large summary of $\delta^{18} \mathrm{O}-\delta^{13} \mathrm{C}$ isotope values in the primary carbonatites of the world. From literary sources, 1593 paired values $\delta^{18} \mathrm{O}-\delta^{13} \mathrm{C}$ from 173 carbonatite occurrences of the world were collected. This report exceeds all previously published reports on $\mathrm{C}-\mathrm{O}$ isotopes in carbonatites by quantity of the used values and carbonatite occurrences. Statistical data analysis is performed on diagrams in the coordinates $\delta^{18} \mathrm{O}(\%, \mathrm{~V}-\mathrm{SMOW})-\delta^{13} \mathrm{C}(\%$, V-PDV). For each carbonatite occurrence, not only the arithmetic mean values are calculated, but also the regression line. Distinct linear trend of $\delta^{18} \mathrm{O}-\delta^{13} \mathrm{C}$ values is found in half of the carbonatite occurrences. The starting, middle, and ending points of the trend line are determined. The slope of the trend line (angular coefficient) varies over a wide range. The trend is dominated by an average angular coefficient of 0.30 (positive correlation $\delta^{18} \mathrm{O}-\delta^{13} \mathrm{C}$ ). In the literature, it is associated with the Rayleigh high-temperature fractionation of carbonatite melts or with their sedimentary contamination. Half of the carbonatite occurrences do not show a linear trend of $\delta^{8} \mathrm{O}-\delta^{13} \mathrm{C}$ values, probably due to the combined action of multidirectional trends. The initial ratio ${ }^{87} \mathrm{Sr} /{ }^{86} \mathrm{Sr}$ in the used carbonatite occurrences varies from 0.701 to 0.708 . Statistics show no correlation of ${ }^{87} \mathrm{Sr} /{ }^{86} \mathrm{Sr}$ with the $\delta^{18} \mathrm{O}-\delta^{13} \mathrm{C}$ system.
\end{abstract}

\section{Keywords}

Carbonatite Occurrences, Oxygen, Carbon and Strontium Isotopes, Linear Trends

\section{Introduction}

Oxygen and carbon isotope composition of carbonatites were summarized in a 
number of previous works. The largest number of $\delta^{18} \mathrm{O}-\delta^{13} \mathrm{C}$ values (about 440) was collected and used to construct histograms in [1]. In the work [2], 56 values from 8 carbonatite occurrences of Kola Alkaline Province were used, linear trends were identified. In the work [3], 70 analyzes from 20 carbonatite occurrences of Siberia and Mongolia were used; a diagram was proposed for determining the type of mantle using the ratio of O-C isotopes. In the work [4], the fields of point values are outlined in the $\delta^{18} \mathrm{O}-\delta^{13} \mathrm{C}$ diagram for the Greenland, Europe, and North and South America regions without a division for individual carbonatite occurrences. The fields of primary igneous carbonatites on the $\delta^{18} \mathrm{O}-\delta^{13} \mathrm{C}$ diagram are outlined in the works [1] [5] [6] [7]. These fields are used in the analysis of local isotope data in carbonatite studies.

This paper uses 1593 pairs of conjugate values of $\delta^{18} \mathrm{O}-\delta^{13} \mathrm{C}$ out of 173 carbonatite occurrences of the world. In addition, a linear regression analysis of the values is performed for most occurrences. This paper exceeds all previously published reports on $\mathrm{C}-\mathrm{O}$ isotopes in carbonatites by quantity of the used values and carbonatite occurrences. Data on the ratio ${ }^{87} \mathrm{Sr} /{ }^{86} \mathrm{Sr}$ in 92 carbonatite occurrences are taken additionally from the sources used. The limited size of the article does not allow to provide a complete database and a list of used references (about 100 titles).

Carbonatite occurrences are represented by bodies of various shapes and sizes (complexes, massifs, dikes, facies zones). Isotope analysis is applied to carbonatite rocks (sovite, alvikite, beforsite, etc.), monofractions of calcite, dolomite, ankerite, siderite. Authors of literature classify the analyzed material as primary carbonatites (PC). This is mainly done on the basis of petrographic studies, in which secondary endo- and exogenous minerals are not detected. Single anomalous values are excluded from the primary category by the author of the article. Numerous $\delta^{18} \mathrm{O}-\delta^{13} \mathrm{C}$ values refer to secondary carbonatites in the used literature: carbonate tuffs and lavas, hydrothermal veins, hydrothermally altered and recrystallized carbonatites, weathered and oxidized carbonatites, secondary calcite. Data on secondary carbonatites is not used in this article.

All isotope diagrams have a horizontal $x$-axis $\delta^{18} \mathrm{O}(\%$, V-SMOW) and a vertical $y$-axis $\delta^{13} \mathrm{C}(\%, \mathrm{~V}-\mathrm{PDV})$. The equal scale of both axes, a multiple of $1 \%$, allows to visually comparing the shape of the point sets (point fields) and the slope of the trend lines. The names of carbonatite occurrences and their identification number (ID) are coordinated with the database [8] and are given in English transcription.

\section{Summary Data}

The diagram in Figure 1 contains 1593 points of the $\delta^{18} \mathrm{O}-\delta^{13} \mathrm{C}$ from 173 carbonatite occurrences, including various carbonatite facies in one occurrence. The number of points in the individual occurrences varies from 2 to 54 . The points fill a very wide field. Analysis of the field is complex and incorrect due to the variable number and large scatter of points that characterize individual carbonatite occurrences. The contours PC- $98 \%$ and PC-90\% presented in the diagram are proved in Figure 2 and Figure 3. 


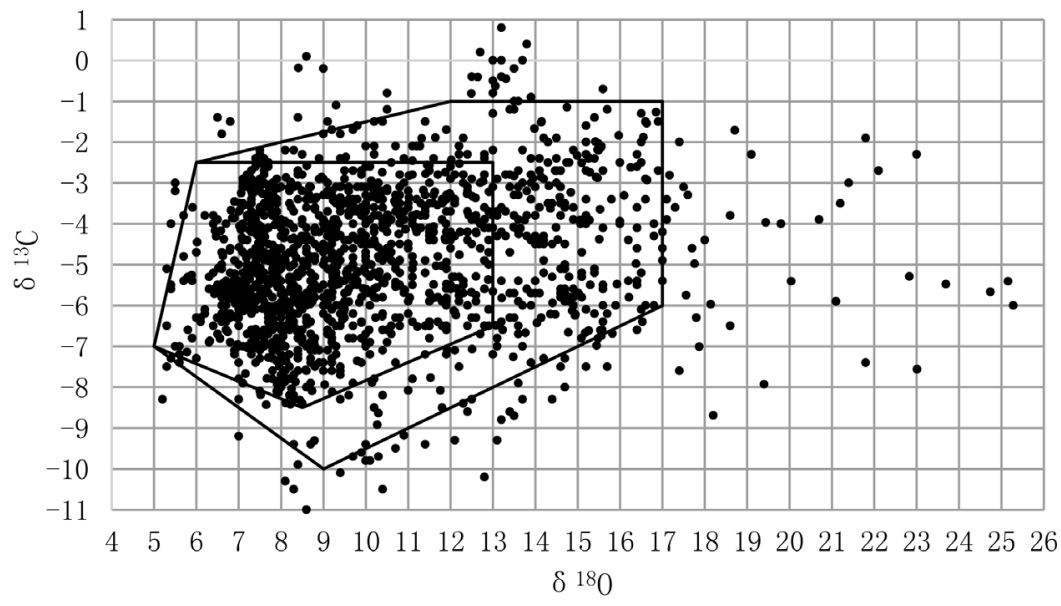

Figure 1. Primary carbonatites (PC) of the world: a summary of $\delta^{18} \mathrm{O}-\delta^{13} \mathrm{C}$ paired values $(\mathrm{n}=1593)$ and contours PC-98\% (external) and PC-90\% (internal).

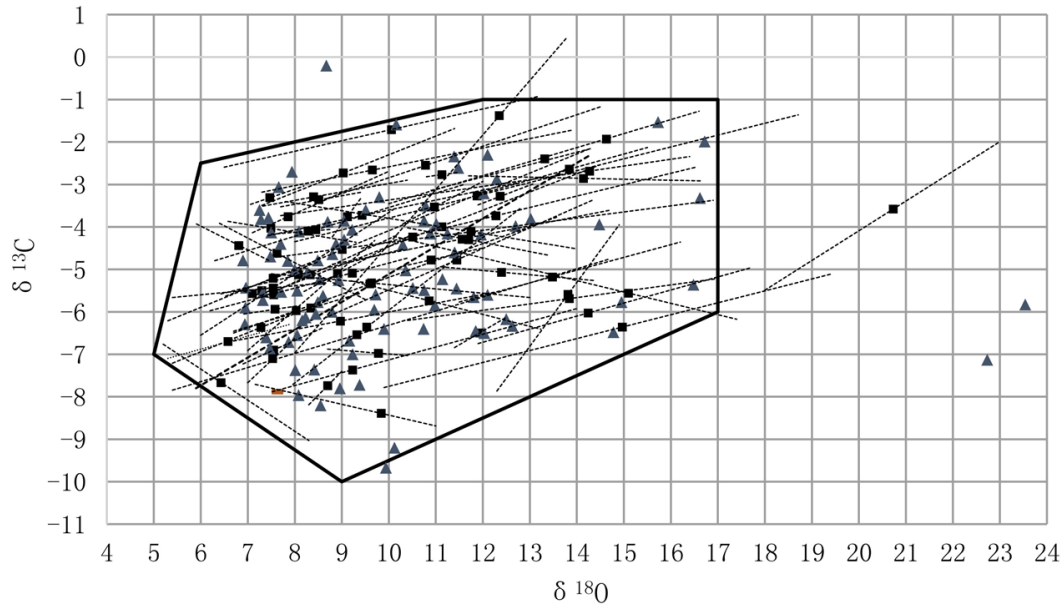

Figure 2. Trend lines and middle points (black square) in occurrences with a linear trend $(\mathrm{n}=70)$. Only middle points (black triangle) in other occurrences $(\mathrm{n}=103)$. Polygonal contour PC-98\% includes $98 \%$ of points.

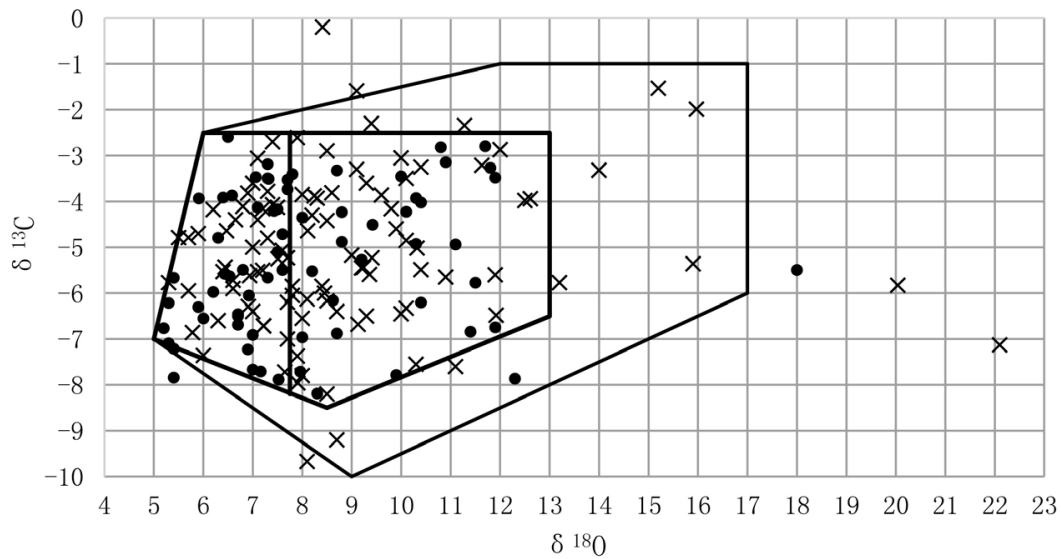

Figure 3. The starting points in occurrences with a linear trend (fat point, $n=70$ ) and in other occurrences (oblique cross, $\mathrm{n}=103$ ). The outer contour PC- $98 \%$. The internal contour PC-90\% includes $90 \%$ of points and is divided into two halves of PC- $45 \%$. 
Subsequent statistical analysis of isotope data uses summary indicators characterizing carbonatite occurrences. Trend (linear regression) analysis was performed in 140 occurrences that satisfy two conditions: 1) there are three or more points; 2) the arithmetic difference between the maximum and minimum $\delta^{18} \mathrm{O}$ values is more than $0.5 \%$. Trend lines under opposite conditions (less than three points and difference $\delta^{18} \mathrm{O}$ less than $0.5 \%$ ) cannot be reliable. The linear regression equation $y=k x+b$ and the trend line are calculated in Microsoft Excel 97-2003. The complete database (it is too large to be here) contains a point diagram for each occurrence, a calculated angular coefficient $k$, a constant $b$, a coefficient of determination (approximation) $\mathrm{R}^{2}$.

Examples of point diagrams in order of increasing coefficient $\mathrm{R}^{2}$ are shown in Figure 4. According to the visual observation of the diagrams, the linear trend is absent or indistinct in the occurrences that have $\mathrm{R}^{2}$ from 0.00 to 0.29 . The number of such occurrences in the database is 70. The linear form of point fields begins to confidently be fixed from $\mathrm{R}^{2} \geq 0.30$ (occurrence 413 . Chetlassky in Figure 4). The linear trend is found in 70 occurrences, where $R^{2}$ is from 0.30 to 0.99 . The trend line is depicted as a vector directed upwards $\delta^{18} \mathrm{O}$. Such a direction is taken in the literature on the geochemistry of carbonatites.

Appendix provides a summary Table with brief data on 173 carbonatite occurrences. The names of occurrences that are not in the database [8] are given without an ID number. Digital data include: 1) $n, n^{*}$ is the number of paired values $\delta^{18} \mathrm{O}-\delta^{13} \mathrm{C}$ in occurrences without a linear trend $(\mathrm{n})$ and with a linear trend $\left.\left(\mathrm{n}^{*}\right) ; 2\right)$ middle point arithmetic average $\delta^{18} \mathrm{O}-\delta^{13} \mathrm{C}$ from among the values; 3 ) the starting point of the trend line or nonlinear field of $\delta^{18} \mathrm{O}-\delta^{13} \mathrm{C}$ points; 4) minimum initial ratio ${ }^{87} \mathrm{Sr} /{ }^{86} \mathrm{Sr}$. The position of carbonatite occurrences in the diagrams (Figure 2 and Figure 3) can be determined using the table values.

Trend line and middle point for 70 occurrences in which a linear trend is revealed are shown in the diagram (Figure 2). Only the middle point is shown for the remaining 103 occurrences. The polygonal contour PC-98\% is delineated. It includes about $98 \%$ of all middle points. The diagram shows that trend lines vary significantly in length. The horizontal span of the lines (the arithmetic difference $\delta^{18} \mathrm{Omax}-\delta^{18} \mathrm{Omin}$ ) ranges from $0.5 \%$ o to $11 \%$, in $90 \%$ of cases it does not exceed $7.5 \%$, on average it is $3.5 \%$.

The slope of the trend line varies widely, as seen in Figure 2. The slope is determined by the angular coefficient $k$. Statistical analysis of the coefficient is shown in Figure 5. Three separate intervals of $\mathrm{k}$ are read on the point diagram: $-0.73-0.09 ; 0.09-0.51 ; 0.51-1.51$. On the rose diagram, the intervals are shown as sectors, and the average for the three sectors is shown as vectors. Sector $\mathrm{k}$ with a range of $0.09-0.51$ and a middle vector of 0.30 is sharply dominant. Sector $-0.73-0.09$ with a middle vector of -0.27 and sector $0.51-1.51$ with a middle vector of 0.96 have a subordinate meaning.

The averaged shape of the field of points for three groups of occurrences with a linear trend and for one group without a trend is modeled in Figure 6. The 

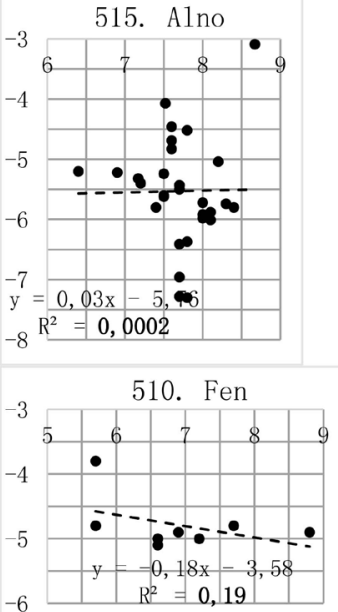

355. Siriwasan
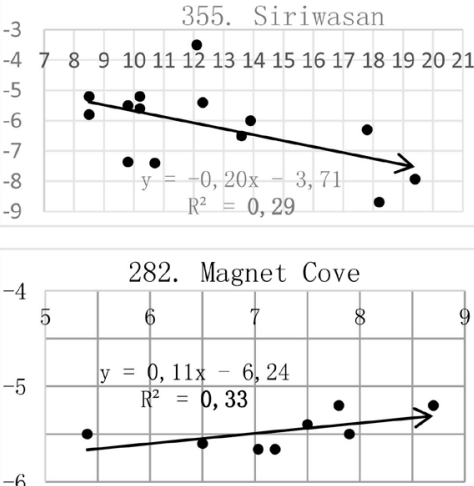

$-6$

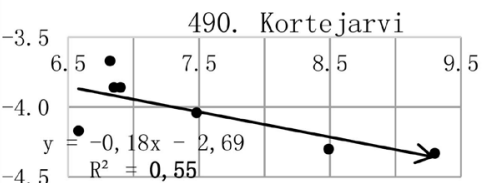

$-4.5-R^{2}=0,55$

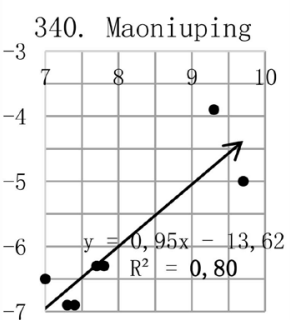

122

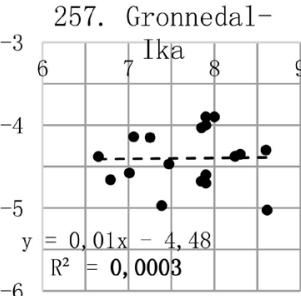

472. South Nam

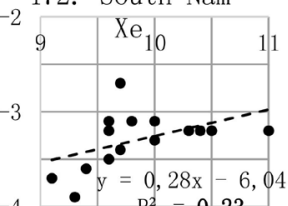

$R^{2}=0,23$

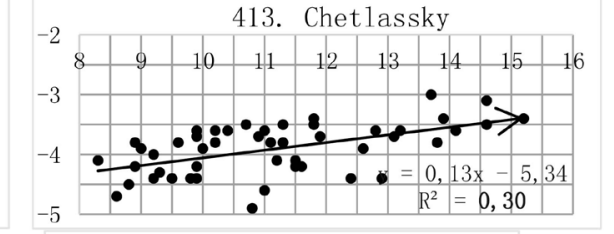

299. Tapira
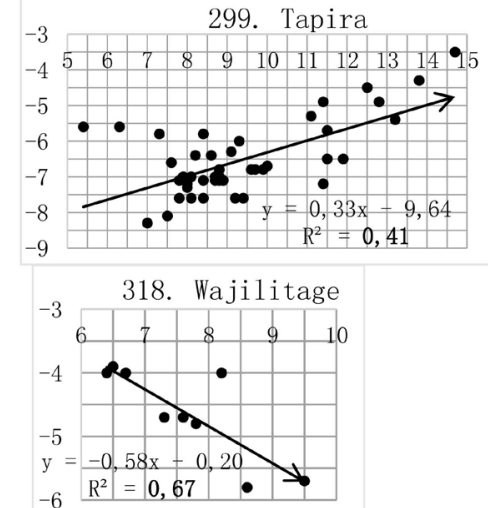

366. Samalpatti
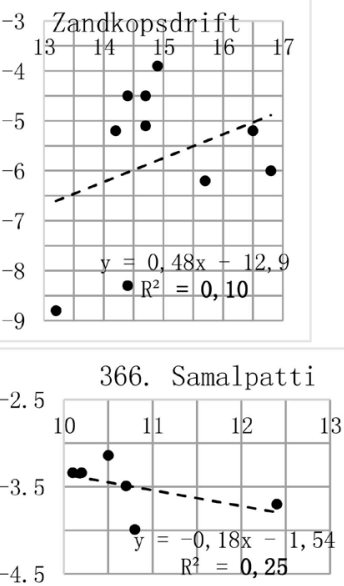

3

$$
54
$$

$-6$

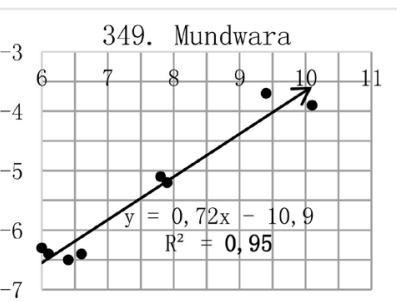

349. Mundwara

Figure 4. Examples of trend analysis of $\delta^{18} \mathrm{O}$ (x-axis, \%o) and $\delta^{13} \mathrm{C}$ (y-axis, \%o) values in carbonatite occurrences in order of increasing coefficient $\mathrm{R}^{2}$.

arithmetic average differences $\delta^{18} \mathrm{Omax}-\delta^{18} \mathrm{Omin}$ and $\delta^{13} \mathrm{Cmax}-\delta^{13} \mathrm{Cmin}$ are calculated in each group. Rectangles with sides equal to these averages are shown in Figures 6(a)-(d). The modeled fields of points are inscribed in rectangles along the middle trend line. All fields in accordance with their averages are placed in Figure 6(e). Comparison of the fields shows that the lack of a clear linear form in the field $6 \mathrm{~d}$ is due to the increased variation in the $\delta^{13} \mathrm{C}$ value. This may be due to the cumulative effect of trends $6 a, 6 b$ and $6 c$. 

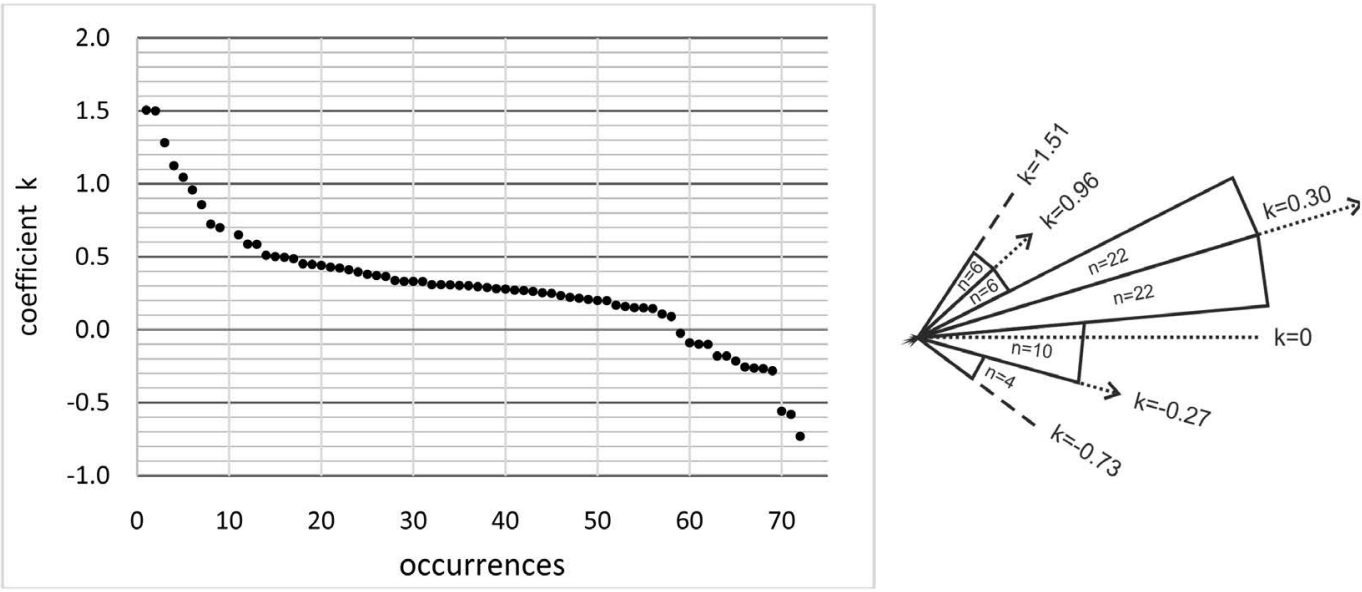

Figure 5. Point diagram (left) and rose diagram (right) of the angular coefficient $\mathrm{k}$ in the regression equation $y=k x+b$ in occurrences with the linear trend $\delta^{18} \mathrm{O}-\delta^{13} \mathrm{C}$. The point diagram shows separate intervals $k$. $-0.73-0.09$ (average -0.27); 0.09 - 0.51 (average 0.30); $0.51-1.51$ (average 0.96).

$\delta^{18} \mathrm{C}$

(a)

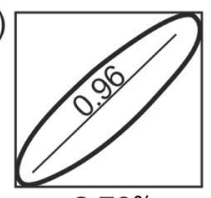

$2.70 \%$

(b)

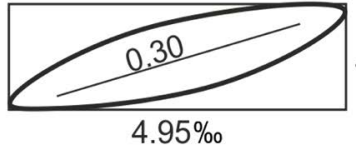

(c)

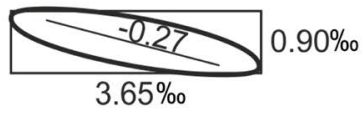

(d)

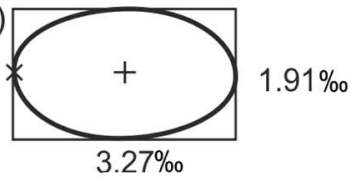

(e)

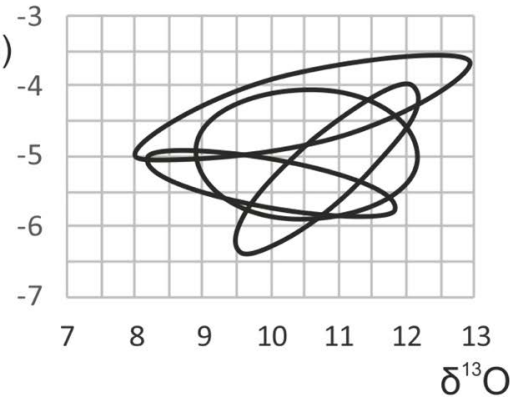

Figure 6. The averaged form of point fields: $(a, b, c)$ occurrences with a linear trend with an angular coefficient of $0.96,0.30$ and -0.27 ; (d) occurrences without a linear trend with a middle point (straight cross) and a starting point (oblique cross); (e) comparison of the fields in the diagram.

Each carbonatite occurrence with a linear trend can be characterized by the starting point of the trend. The $\delta^{18} \mathrm{O}$ of the starting point is equal to the minimum value in the statistical sample. The $\delta^{13} \mathrm{C}$ value is calculated from the empirical regression equation. The values of $\delta^{18} \mathrm{O}-\delta^{13} \mathrm{C}$ starting points of the trends are given in the Table. Occurrences without a linear trend also imply the presence of a starting point. This follows from the previously made assumption that the nonlinear point field $6 \mathrm{~d}$ in Figure 6 is the result of the cumulative influence of trends $6 \mathrm{a}, 6 \mathrm{~b}$ and $6 \mathrm{c}$. All trends are directed upwards $\delta^{18} \mathrm{O}$, but in different directions along $\delta^{13} \mathrm{C}$. Therefore, the starting point of field $6 \mathrm{~d}$ must have $\delta^{18} \mathrm{O}$ equal to the minimum of the statistical sample. The $\delta^{13} \mathrm{C}$ value in some approximation can be taken equal to the average of the sample (Figure 6(d)). The $\delta^{18} \mathrm{O}-\delta^{13} \mathrm{C}$ of the starting point in the occurrences without the identified linear 
trend is also given in the Table.

The diagram shows two groups of points (Figure 3): 1) the starting point of the trend line in the occurrences with a linear trend $(n=70) ; 2)$ the starting point of nonlinear fields in other occurrences $(n=103)$. The second group includes occurrences without a linear trend $(n=70)$, and also occurrences with only two points $\delta^{18} \mathrm{O}-\delta^{13} \mathrm{C}(\mathrm{n}=24)$ and with a difference $\delta^{18} \mathrm{Omax}-\delta^{18} \mathrm{Omin}<$ $0.5(\mathrm{n}=9)$ that were excluded from the trend analysis. Visual analysis of the diagram allows to delineate the internal contour PC-90\% in addition to the PC-98\% contour justified in Figure 2. This contour includes a compact group of $90 \%$ starting points. The vertical line $\delta^{18} \mathrm{O}=7.9 \%$ divides the contour PC- $90 \%$ into two parts, each of which is $45 \%$ of the total number of starting points.

The contours of primary carbonatites PC-98\%, PC-90\% and PC- $45 \%$ (left and right contours) are shown in the diagram (Figure 7). For comparison, the contours and points of primary igneous (mantle) carbonatites are given according to other authors. The closest is the left contour of PC- $45 \%$ and the contour of Jones et al. [7]. The three middle vectors of the angular coefficient $k$ are also shown in the diagram. The dominant trend $k=0.30$ in the literature is usually associated with two factors that coincide in direction: 1) Rayleigh isotopic fractionation at high-temperature differentiation of carbonatite melts; 2) sedimentation (crustal) contamination of mantle melts. The second factor is illustrated by the directionality of the dominant trend on the contour of normal sedimentary rocks. The subordinate trend $k=-0.27$ is associated with the degassing of $\mathrm{CO}_{2}$ from melts. Another subordinate trend $k=0.96$ is not discussed in the literature. The beginning of the vectors is at the point $\left(5 \% 0 \delta^{18} \mathrm{O} ;-6.5 \% 0 \delta^{13} \mathrm{C}\right)$. The full sector of the angular coefficient (from -0.73 to 1.51 ) covers almost all occurrences from this point. Perhaps this point is close to the primary mantle source of carbonatites.

The used literature on $\mathrm{O}-\mathrm{C}$ isotopy also contains data on the isotope composition of strontium. The minimum initial value of ${ }^{87} \mathrm{Sr} /{ }^{86} \mathrm{Sr}$ in 92 carbonatite occurrences is given in the Table. The field of minimum values in the coordinates ${ }^{87} \mathrm{Sr} /{ }^{86} \mathrm{Sr}-\delta^{88} \mathrm{O}$ is presented in the diagram (Figure 8 ). There is no correlation between the values. The oblique line in the diagram is the line of mixing the mantle source $\left({ }^{87} \mathrm{Sr} /{ }^{86} \mathrm{Sr}=0.702 ; \delta^{88} \mathrm{O}=5 \%\right.$ o) and the sedimentary contaminant ${ }^{87} \mathrm{Sr} /{ }^{86} \mathrm{Sr}=0.710 ; \delta^{18} \mathrm{O}=20 \%$ o) at equal concentrations of strontium in the sources. The stable enrichment of carbonatites with strontium in comparison with sedimentary carbonates is known. Under this condition, a band of points above the mixing line may reflect crustal contamination of magmas. However, a wide scatter of points below the mixing line leaves room for other hypotheses, including contamination of the source in the mantle. The PC-98\%, PC-90\% and PC- $45 \%$ contours, previously substantiated in the coordinates $\delta^{18} \mathrm{O}-\delta^{13} \mathrm{C}$, are delineated in the diagram. The PC- $45 \%$ contour is divided by the value ${ }^{87} \mathrm{Sr} /{ }^{86} \mathrm{Sr}=$ 0.704 into two fields. The field ${ }^{87} \mathrm{Sr} /{ }^{86} \mathrm{Sr}<0.704$ and $\delta^{18} \mathrm{O}<7.75 \%$ can be considered as the primary mantle field in the $\mathrm{O}-\mathrm{C}-\mathrm{Sr}$ isotope system. 


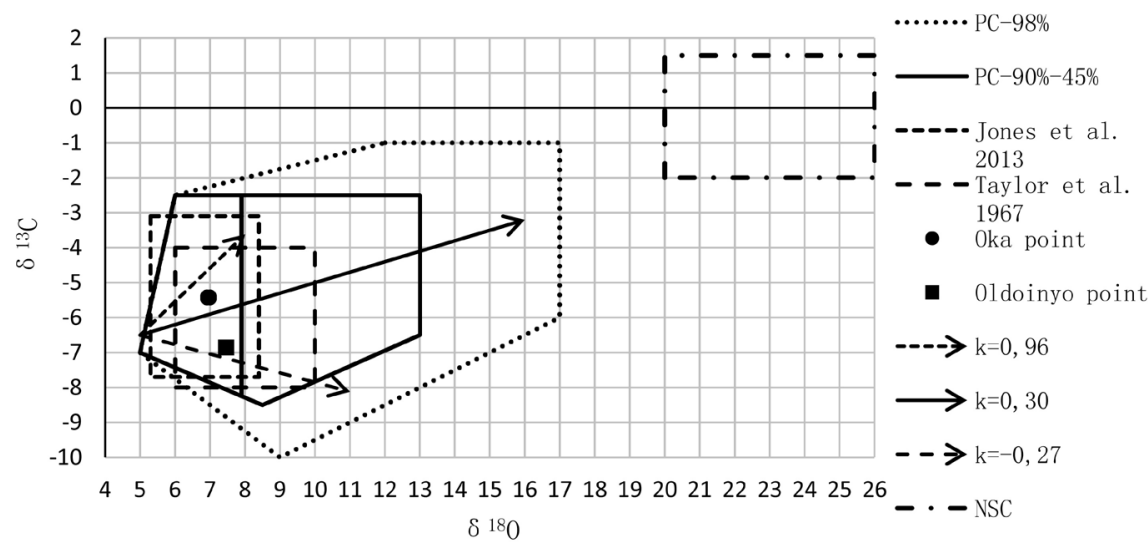

Figure 7. Fields and points of primary igneous carbonatites and middle trend vectors. NSC_-normal sedimentary carbonates.

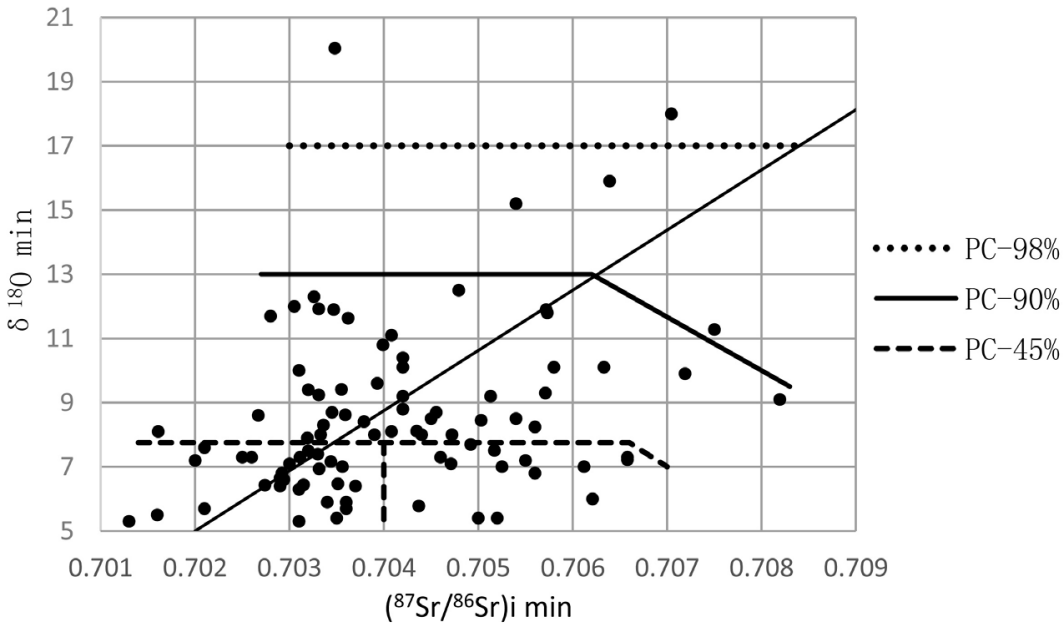

Figure 8. The isotope composition of strontium (minimum initial value) and oxygen (starting point) in carbonatite occurrences.

\section{Conclusions}

Data on the oxygen and carbon isotope composition of primary carbonatites for 173 carbonatite occurrences of the world were collected (1593 paired values of $\left.\delta^{18} \mathrm{O}-\delta^{13} \mathrm{C}\right)$. Primary carbonatites are rocks without petrographic signs of secondary hydrothermal and exogenous mineral changes. Primary carbonatites demonstrate a wide variation of the $\delta^{18} \mathrm{O}-\delta^{13} \mathrm{C}$ values and linear trends, which indicates the isotopic heterogeneity of carbonatite substance.

Linear regression analysis of $\delta^{18} \mathrm{O}-\delta^{13} \mathrm{C}$ values reveals linear trends in half of the carbonatite occurrences. The trend with an average angular coefficient of 0.30 (positive correlation $\delta^{18} \mathrm{O}-\delta^{13} \mathrm{C}$ ) sharply dominates. In the literature, this is explained by the Rayleigh high-temperature fractionation of carbonatite melts or by their sedimentary (crustal) contamination. The trend line span (arithmetic difference $\delta^{18} \mathrm{Omax}-\delta^{88} \mathrm{Omin}$ ) ranges from $0.5 \%$ to $11 \%$, on average it is $3.5 \%$. Increased trends (over 7.5\%) suggest the action not only of endogenous factors, but also the influence of secondary processes not recorded in petrographic ob- 
servations.

The second trend with an average angular coefficient of -0.27 (negative correlation $\left.\delta^{18} \mathrm{O}-\delta^{13} \mathrm{C}\right)$ is rarer. This trend is usually associated with the $\mathrm{CO}_{2}$ degassing from melts. A rare third trend is not discussed in the literature. It has an average angular coefficient of 0.96 (positive correlation $\delta^{18} \mathrm{O}-\delta^{13} \mathrm{C}$ ). The linear trend of $\delta^{18} \mathrm{O}-\delta^{13} \mathrm{C}$ values is not detected in half of carbonatite occurrences due to increased variation of $\delta^{13} \mathrm{C}$. This may be due to the combined action of different factors-contamination, high-temperature fractionation and degassing of melts.

The fields of primary carbonatites (PC) are delineated in the coordinates $\delta^{18} \mathrm{O}-\delta^{13} \mathrm{C}(\%)$, including $98 \%, 90 \%$ and $45 \%$ of the numbers of occurrences. The PC-90\% contour can be considered acceptable for primary carbonatites. In-depth petrographic and other argumentation of the primary nature of carbonates is required for occurrences outside this contour. The PC-45\% $\left(\delta^{18} \mathrm{O}<\right.$ $7.75 \%$ ) contour with a high probability includes only primary carbonatites with a mantle source of a carbonate substance and with minimal effect of isotope fractionation or contamination of melts. A greater influence of these factors is expected for occurrences in the PC- $45 \%\left(\delta^{18} \mathrm{O}>7.75 \%\right.$ o $)$ contour.

Strontium in carbonatite occurrences has a wide variation of the initial ${ }^{87} \mathrm{Sr} /{ }^{86} \mathrm{Sr}$ ratio from 0.701 to 0.708 . This variation and the absence of correlation between ${ }^{87} \mathrm{Sr} /{ }^{86} \mathrm{Sr}$ and the $\delta^{18} \mathrm{O}-\delta^{13} \mathrm{C}$ allow both mantle and crustal contamination of carbonatite magmas.

The stated statistical data on the $\mathrm{O}, \mathrm{C}$ and $\mathrm{Sr}$ isotope composition in primary carbonatites leave room for additional and alternative judgments.

\section{Conflicts of Interest}

The author declares no conflicts of interest regarding the publication of this paper.

\section{References}

[1] Deines, P. (1989) Stable Isotope Variations in Carbonatites. Carbonatites: Genesis and Evolution. Unwin Hyman, London, 301-359.

[2] Demény, A., Sitnikova, M.A. and Karchevsky, P.I. (2004) Stable C and O Isotope Compositions of Carbonatite Complexes of the Kola Alkaline Province: Phoscorite-Carbonatite Relationships and Source Compositions. In: Wall, F. and Zaitsev, A.N., Eds., Phoscorites and Carbonatites from Mantle to Mine, Mineralogical Society Series 10, Mineralogical Society, London, 407-431. https://doi.org/10.1180/MSS.10.12

[3] Vladykin, N.V., Morikiyo, T., Miyazaki, T. and Tsypukova, S.S. (2004) Geochemistry of Carbon and Oxygen Isotopes of Siberian Carbonatites and Geodynamics. Deep Magmatism, Its Sources and Their Connection with Plume Processes, Irkutsk. 89-107. (In Russian)

[4] Bell, K. and Simonetti, A. (2010) Source of Parental Melts to Carbonatites-Critical Isotopic Constraints. Mineralogy and Petrology, 98, 77-89.

https://doi.org/10.1007/s00710-009-0059-0 
[5] Taylor, H.P., Frechen, J. and Degens, E.T. (1967) Oxygen and Carbon Isotope Studies of Carbonatites from the Laacher See District, West Germany and the Alnö District, Sweden. Geochimica et Cosmochimica Acta, 31, 407-430. https://doi.org/10.1016/0016-7037(67)90051-8

[6] Keller, I. and Hoefs, I. (1995) Stable Isotope Characteristics of Recent Natrocarbonatite from Oldoinyo Lengai. In: Bell, K. and Keller, J., Eds., Carbonatite Volcanism: Oldoinyo Lengai and the Petrogenesis of Natrocarbonatites, Proceedings in Volcanology, Vol. 4, Springer, Berlin, 113-123.

https://doi.org/10.1007/978-3-642-79182-6 9

[7] Jones, A.P., Genge, M. and Carmody, L. (2013) Carbonate Melts and Carbonatites. Reviews in Mineralogy \& Geochemistry, 75, 289-322. https://doi.org/10.2138/rmg.2013.75.10

[8] Woolley, A.R. and Kjarsgaard, B.A. (2008) Carbonatite Occurrences of the World: Map and Database. Geological Survey of Canada, Ottawa.

https://doi.org/10.4095/225115 


\section{Appendix}

Carbonatite occurrences: $\delta^{18} \mathrm{O}-\delta^{13} \mathrm{C}$ values of middle and starting points of trends; minimum initial ratio ${ }^{87} \mathrm{Sr} /{ }^{86} \mathrm{Sr}\left(\mathrm{n}^{*}\right.$ - occurrences with a linear trend, $\mathrm{n}$ - other occurrences)

\begin{tabular}{|c|c|c|c|c|c|c|c|c|c|}
\hline \multirow{2}{*}{ ID } & \multirow{2}{*}{ Occurrence note } & \multirow{2}{*}{ Country } & \multirow{2}{*}{ Literary source } & \multirow{2}{*}{$\mathrm{n}, \mathrm{n}^{*}$} & \multicolumn{2}{|c|}{ Middle point } & \multicolumn{3}{|c|}{ Starting point } \\
\hline & & & & & $\delta^{18} \mathrm{O}$ & $\delta^{13} \mathrm{C}$ & $\delta^{18} \mathrm{O}$ & $\delta^{13} \mathrm{C}$ & ${ }^{87} \mathrm{Sr} /{ }^{86} \mathrm{Sr}$ \\
\hline 1 & 2 & 3 & 4 & 5 & 6 & 7 & 8 & 9 & 10 \\
\hline 1 & InOuzzal & Algeria & Ouzegane et al., 1988 & 7 & 9.38 & -7.72 & 7.65 & -7.72 & - \\
\hline 5 & Bailundo & Angola & Pineau et al.,1973; Alberti et al., 1999 & $8^{*}$ & 9.60 & -5.34 & 6.70 & -6.50 & - \\
\hline 6 & Monte Verde & Angola & Pineau et al.,1973; Alberti et al., 1999 & $15^{*}$ & 9.01 & -4.53 & 5.30 & -6.21 & - \\
\hline 10 & Tchivira-Bonga & Angola & Alberti et al., 1999 & $7^{*}$ & 12.28 & -3.74 & 9.42 & -4.51 & - \\
\hline 15 & Lupongola & Angola & Alberti et al., 1999 & $10^{*}$ & 9.23 & -7.37 & 7.52 & -7.88 & - \\
\hline 16 & Matongo & Bourundi & Dolenek et al., 2015; Decree et al., 2015 & $13^{*}$ & 7.54 & -5.21 & 6.53 & -5.63 & - \\
\hline 19 & Lueshe & Congo & Самойлов, 1984 & 2 & 7.90 & -5.85 & 7.80 & -5.85 & - \\
\hline 21 & Wadi Tarr & Egypt & Shimron, 1975 & $3^{*}$ & 6.43 & -7.67 & 5.20 & -6.76 & - \\
\hline 29 & Rangwa & Kenya & Suva et al., 1975 & $5^{*}$ & 15.10 & -5.56 & 10.10 & -4.22 & 0.7042 \\
\hline 33 & Homa Mountain & Kenya & Dennis and Schrag, 2010 & $8^{*}$ & 8.51 & -3.36 & 7.70 & -3.52 & - \\
\hline 34 & Buru-siderite & Kenya & Onuonga, 1997 & 16 & 14.48 & -3.94 & 12.61 & -3.94 & - \\
\hline 39 & Kangankunde & Malawi & $\begin{array}{c}\text { Dennis and Schrag, 2010; Nelson, 1987; } \\
\text { Broom-Fendley et al., } 2017\end{array}$ & 9 & 8.49 & -4.79 & 5.50 & -4.79 & 0.7016 \\
\hline 47 & Chilwa Island & Malawi & Simonetti and Bell, 1994 & 16 & 11.48 & -2.61 & 7.90 & -2.61 & 0.7032 \\
\hline 48 & Tundulu & Malawi & Самойлов, 1984 & 2 & 12.35 & -3.25 & 10.40 & -3.25 & - \\
\hline 51 & Songwe Hill & Malawi & Broom-Fendley et al., 2016 & $4^{*}$ & 11.13 & -4.00 & 7.80 & -3.40 & - \\
\hline 64 & Tamazert & Morocco & $\begin{array}{l}\text { Bouabdellah et al., 2010; } \\
\quad \text { Marks et al., } 2009\end{array}$ & 42 & 8.60 & -5.62 & 6.94 & -5.62 & 0.7033 \\
\hline 73 & Xiluvo & Mozambique & Melluso et al., 2004 & $3^{*}$ & 9.63 & -5.32 & 7.50 & -5.10 & 0.7032 \\
\hline 75 & Swartbooisdrif & Namibia & Thompson et al., 2002 & 2 & 8.01 & -7.37 & 7.90 & -7.37 & \\
\hline 78 & Okorusu & Namibia & Le Roex and Lanyon, 1998 & 2 & 8.80 & -4.64 & 8.11 & -4.64 & 0.7043 \\
\hline 79 & Ondurakorume & Namibia & Le Roex and Lanyon, 1998 & 2 & 8.80 & -4.64 & 6.47 & -4.64 & 0.7035 \\
\hline 82 & Lofdal & Namibia & Vistorina Nandigolo, 2013 & $3^{*}$ & 8.08 & -5.13 & 6.43 & -5.57 & 0.7027 \\
\hline 89 & Dicker Willem & Namibia & Reid and Cooper, 1992 & 2 & 8.00 & -5.00 & 7.00 & -5.00 & - \\
\hline 103 & Phalaborwa & S. Africa & Suwa et al., 1975 & 4 & 9.05 & -3.85 & 8.00 & -3.85 & 0.7039 \\
\hline 105 & Spitskop-calcite & S. Africa & Harmer, 1999; Suwa et al., 1975 & $8^{*}$ & 14.14 & -2.86 & 11.70 & -2.80 & 0.7028 \\
\hline 105 & Spitskop-dolomite & S. Africa & Harmer, 1999; Suwa et al., 1975 & 7 & 16.72 & -1.99 & 15.97 & -1.99 & - \\
\hline 108 & Nooltgedacht & S. Africa & Clarke, 1989 & 2 & 9.05 & -4.30 & 8.20 & -4.30 & - \\
\hline 109 & Kruidfonten & S. Africa & Clarke, 1989 & $5^{*}$ & 13.32 & -2.40 & 10.90 & -3.14 & - \\
\hline 113 & Premier Mine & S. Africa & Suwa et al., 1975 & $4^{*}$ & 11.93 & -6.50 & 11.40 & -6.84 & - \\
\hline 122 & Zandkopsdrift & S. Africa & Ogungbuy et al., 2015 & 10 & 14.95 & -5.77 & 13.20 & -5.77 & - \\
\hline 126 & Oldoinyo Lengai & Tanzania & $\begin{array}{l}\text { Bell and Keller, 1995; } \\
\text { Halama et al., } 2007\end{array}$ & 9 & 7.47 & -6.86 & 5.78 & -6.86 & 0.7044 \\
\hline
\end{tabular}




\section{Continued}

\begin{tabular}{|c|c|c|c|c|c|c|c|c|c|}
\hline 127 & Kerimasi & Tanzania & Zaitsev et al., 2013 & $3^{*}$ & 9.43 & -3.73 & 7.43 & -4.20 & - \\
\hline 142 & Panda Hill (Mbeya) & Tanzania & $\begin{array}{l}\text { Suwa et al., 1975; Dennis and } \\
\text { Schrag, 2010: Dolenek et al., } 2015\end{array}$ & 13 & 7.48 & -4.70 & 5.90 & -4.70 & 0.7034 \\
\hline 155 & Bukusu & Uganda & Самойлов, 1984 & 2 & 10.40 & -2.90 & 8.50 & -2.90 & - \\
\hline 156 & Tororo & Uganda & Nelson, 1987; Dennis, 2010 & $10^{*}$ & 9.03 & -2.73 & 7.30 & -3.49 & 0.7025 \\
\hline 157 & Sukulu & Uganda & Deines and Gold, 1973 & $8^{*}$ & 9.65 & -2.66 & 7.30 & -3.18 & 0.7026 \\
\hline 173 & Aley-calcite & Canada & $\begin{array}{c}\text { Mader, 1986; } \\
\text { Chakhmouradian et al., } 2015\end{array}$ & 6 & 8.53 & -5.23 & 7.70 & -5.23 & - \\
\hline 176 & Wicheeda-calcite & Canada & Trofanenko, 2014 & 2 & 6.94 & -6.29 & 6.91 & -6.29 & - \\
\hline 176 & Wicheeda-dolomite & Canada & Trofanenko, 2014 & 4 & 9.72 & -5.59 & 9.36 & -5.59 & - \\
\hline 191 & Eden Lake & Canada & Chakhmouradian et al., 2008 & 9 & 8.08 & -7.96 & 7.91 & -7.96 & - \\
\hline 196 & Albany Forks & Canada & Suva et al., 1975 & 9 & 10.30 & -4.42 & 8.50 & -4.42 & - \\
\hline 229 & St-Andre & Canada & Suva et al., 1975 & $13^{*}$ & 10.78 & -2.55 & 8.70 & -3.32 & - \\
\hline 230 & Oka & Canada & $\begin{array}{l}\text { Dennis and Schrag, 2010; Chen and } \\
\text { Simonetti, 2015; Haynes et al., } 2003\end{array}$ & 26 & 6.96 & -5.43 & 6.44 & -5.43 & 0.7032 \\
\hline 243 & Aillik Bay-dolomite & Canada & Tappe et al., 2006 & $3^{*}$ & 11.13 & -2.77 & 10.80 & -2.82 & 0.7040 \\
\hline 243 & Aillik Bay-dol-calc & Canada & Tappe et al., 2006 & 11 & 10.75 & -3.86 & 9.60 & -3.86 & 0.7039 \\
\hline- & Paint Lake & Canada & Chakhmouradian et al., 2010 & 2 & 8.45 & -6.05 & 7.80 & -6.05 & - \\
\hline- & Wekusko Lake & Canada & Chakhmouradian et al., 2009 & 7 & 23.54 & -5.83 & 20.04 & -5.83 & 0.7035 \\
\hline 249 & Gardiner & Greenland & Nielsen and Buchardt, 1985 & $3^{*}$ & 10.97 & -3.53 & 10.30 & -3.93 & - \\
\hline 253 & Sarfartog & Greenland & Tappe et al., 2011 & 2 & 12.02 & -3.21 & 11.63 & -3.21 & 0.7036 \\
\hline 257 & Grcnnedal-Ika & Greenland & $\begin{array}{l}\text { Pearc 1997; Coulson et al., 2003; } \\
\text { Halama et al., } 2005\end{array}$ & 18 & 7.70 & -4.40 & 6.65 & -4.40 & 0.7029 \\
\hline 258 & Qaqarssuk-olivine sövite & Greenland & Knudsen and Buchardt, 1991 & $7^{\star}$ & 7.47 & -3.31 & 7.06 & -3.47 & - \\
\hline 258 & Qaqarssuk-sövite & Greenland & Knudsen and Buchardt, 1991 & 4 & 7.28 & -3.82 & 6.90 & -3.82 & - \\
\hline 258 & Qaqarssuk-dolomite sövite & Greenland & Knudsen and Buchardt, 1991 & $5^{*}$ & 8.40 & -3.29 & 7.32 & -3.51 & - \\
\hline 260 & Igaliko & Greenland & Coulson et al., 2003 & 9 & 13.02 & -3.81 & 8.60 & -3.81 & 0.7027 \\
\hline 263 & Bearpaw Mount. & USA & Dennis and Schrag, 2010 & $8^{*}$ & 8.70 & -7.74 & 8.30 & -8.19 & - \\
\hline 265 & Bear Lodge & USA & Moore, 2014 & 10 & 10.12 & -9.20 & 8.70 & -9.20 & 0.7046 \\
\hline 272 & Wet Mountains & USA & Armbrustmacher, 1979 & 4 & 8.88 & -4.40 & 7.10 & -4.40 & - \\
\hline 275 & Iron Hill & USA & Jones et al., 2013; Hugh et al., 1966 & $3^{*}$ & 8.33 & -5.13 & 7.30 & -5.66 & 0.7046 \\
\hline 282 & Magnet Cove & USA & Haynes et al., 2003; Nelson et al., 1988 & $8^{*}$ & 7.30 & -5.50 & 5.40 & -5.66 & 0.7035 \\
\hline 285 & Cerro Sapo & Bolivia & Schultz et al., 2004 & $4^{*}$ & 9.84 & -8.39 & 7.16 & -7.71 & 0.7034 \\
\hline 286 & Chiaracke & Bolivia & Schultz et al., 2004 & 3 & 12.10 & -5.60 & 11.90 & -5.60 & 0.7035 \\
\hline 289 & Angico dos Dias & Brazil & Antonini et al., 2003 & 16 & 14.78 & -6.48 & 11.92 & -6.48 & 0.7033 \\
\hline 293 & Catalao II & Brazil & Vincenza Guarino et al., 2016 & 10 & 8.79 & -6.00 & 8.45 & -6.00 & 0.7050 \\
\hline 294 & Catalao I & Brazil & P. F. de Oliveira Cordeiro et al., 2011 & $5^{*}$ & 10.86 & -5.74 & 9.20 & -5.27 & 0.7051 \\
\hline 296 & Salitre & Brazil & Brod, 1999 & $12^{*}$ & 7.55 & -6.90 & 6.90 & -7.23 & - \\
\hline 298 & Araxa & Brazil & Santos and Clayton, 1995 & $4^{*}$ & 9.78 & -6.98 & 8.70 & -6.88 & - \\
\hline
\end{tabular}




\section{Continued}

\begin{tabular}{|c|c|c|c|c|c|c|c|c|c|}
\hline 299 & Tapira & Brazil & Brod, 1999 & $45^{\star}$ & 9.32 & -6.54 & 5.40 & -7.84 & 0.7052 \\
\hline 303 & Jacupiranga & Brazil & $\begin{array}{l}\text { Gomide et al., 2016; } \\
\text { Comin-Chiaramonti et al., 2007; } \\
\text { Haynes et al., 2003; Nelson, } 1987\end{array}$ & $25^{*}$ & 7.28 & -6.37 & 5.40 & -7.21 & 0.7050 \\
\hline 305 & Barra do Itapirapua & Brazil & Andrade et al., 1999 & $9^{*}$ & 8.34 & -5.91 & 6.70 & -6.46 & - \\
\hline 306 & Mato Preto & Brazil & $\begin{array}{c}\text { Santos and Clayton, 1995; } \\
\text { Andrade et al., 1999; } \\
\text { Comin-Chiaramonti et al., } 2001\end{array}$ & $20^{*}$ & 12.35 & -1.38 & 8.00 & -6.96 & 0.7047 \\
\hline 310 & Chiriguelo & Paraguay & Censi et al., 1989; Castorina et al., 1997 & $20^{*}$ & 14.97 & -6.36 & 9.90 & -7.78 & 0.7072 \\
\hline 318 & Wajilitage & China & W. Song et al., 2017 & $9^{*}$ & 7.62 & -4.62 & 6.40 & -3.91 & 0.7037 \\
\hline 323 & Bayan Obo-dike & China & Yang X et al., 2000; Le Bas 2000 & $12^{*}$ & 14.24 & -6.03 & 11.90 & -6.75 & - \\
\hline- & South Qinling & China & C. Xu et al., 2014 & $17^{\star}$ & 11.45 & -4.78 & 8.62 & -6.16 & 0.7036 \\
\hline- & Qieganbulake & China & H.-M. Ye et al., 2013 & 7 & 8.70 & -3.88 & 8.24 & -3.88 & 0.7056 \\
\hline 332 & Dashigou & China & C. Xu et al., 2010 & 6 & 7.87 & -6.71 & 7.22 & -6.71 & - \\
\hline 332 & Yuantou & China & C. Xu et al., 2010 & 2 & 9.16 & -6.68 & 9.13 & -6.68 & - \\
\hline 337 & Miaoya & China & Çimen et al., 2018 & 10 & 11.14 & -5.23 & 9.41 & -5.23 & 0.7036 \\
\hline 338 & Shaxiongdong & China & C. Xu et al., 2008 & $5^{*}$ & 7.58 & -5.94 & 6.92 & -6.05 & - \\
\hline 340 & Maoniuping & China & Z. Hou et al., 2009 & $7^{\star}$ & 8.03 & -5.97 & 7.00 & -6.91 & 0.7061 \\
\hline 340 & Muluozhai & China & Z. Hou et al., 2009 & 5 & 8.70 & -6.72 & 7.22 & -6.72 & 0.7066 \\
\hline 340 & Lizhuang & China & Z. Hou et al., 2009 & 2 & 11.00 & -4.85 & 10.10 & -4.85 & 0.7063 \\
\hline 346 & Sarnu-Dandali & India & Ray and Ramesh, 1999; Ray et al., 2000 & $7^{*}$ & 8.91 & -5.10 & 8.20 & -5.52 & - \\
\hline 349 & Mundwara & India & Ray and Ramesh, 1999; Ray et al., 2000 & $8^{*}$ & 7.54 & -5.44 & 6.00 & -6.55 & - \\
\hline 350 & Newania & India & Viladkar and Ramesh, 2014 & $7^{\star}$ & 10.51 & -4.24 & 7.60 & -5.49 & 0.7021 \\
\hline 355 & Siriwasan & India & Viladkar and Gittins, 2016 & 14 & 12.50 & -6.17 & 8.50 & -6.17 & 0.7054 \\
\hline 356 & Amba Dongar & India & $\begin{array}{l}\text { Gwalani et al., 2010; Viladkar and } \\
\text { Ramesh, 2014; Simonetti et al., } 1995\end{array}$ & 48 & 10.88 & -4.16 & 7.20 & -4.16 & 0.7055 \\
\hline 356 & Amba Dongar-dike & India & $\begin{array}{l}\text { Viladkar and Ramesh, 2014; } \\
\text { Gwalani et al., } 2010\end{array}$ & $21^{\star}$ & 11.75 & -4.11 & 7.60 & -4.71 & - \\
\hline 357 & Swangkre & India & Ray et al., 1999 & 7 & 9.51 & -3.60 & 9.30 & -3.60 & - \\
\hline 358 & Sung Valley & India & $\begin{array}{l}\text { Ray et al., 1999; Srivastava et al., 2005; } \\
\text { Viladkar and Ramesh, } 2014\end{array}$ & 35 & 7.66 & -3.06 & 7.10 & -3.06 & 0.7047 \\
\hline 360 & Samchampi & India & Ray et al., 1999 & 11 & 7.25 & -3.60 & 7.00 & -3.60 & - \\
\hline 365 & Hogenakkal & India & Pandit, 2002 & 4 & 8.23 & -6.13 & 8.10 & -6.13 & 0.7016 \\
\hline 366 & Samalpatti & India & Ackerman et al., 2017 & 6 & 10.78 & -3.50 & 10.10 & -3.50 & 0.7058 \\
\hline 367 & Sevattur & India & $\begin{array}{l}\text { Pandit, 2003; Kumar et al., 1998; } \\
\text { Ackerman et al., } 2017\end{array}$ & 12 & 8.93 & -5.25 & 7.51 & -5.25 & 0.7052 \\
\hline 369 & Mulakkadu & India & Pandit, 2002 & 5 & 7.44 & -3.78 & 7.30 & -3.78 & 0.7066 \\
\hline 378 & Matcha & Kirgystan & Vrublevskii, 2017 & $9^{*}$ & 20.73 & -3.58 & 18.00 & -5.49 & 0.7070 \\
\hline 379 & Hongcheon & S. Korea & Kim et al., 2005; Kwon and Yeang, 2003 & $7^{*}$ & 9.53 & -6.36 & 7.96 & -7.71 & - \\
\hline- & Yonghwa & S. Korea & Jieun Seo et al., 2016 & 7 & 9.23 & -7.00 & 7.70 & -7.00 & - \\
\hline 380 & Mushugai Khuduk & Mongolia & Владыкин и др., 2004 & 4 & 15.73 & -1.53 & 15.20 & -1.53 & 0.7054 \\
\hline
\end{tabular}




\section{Continued}

\begin{tabular}{|c|c|c|c|c|c|c|c|c|c|}
\hline 383 & Ulugei & Mongolta & Кулешов, 1986 & 12 & 9.94 & -9.67 & 8.10 & -9.67 & 0.7041 \\
\hline- & Zhlobin & Belarussia & Веретенников и др., 2007 & 4 & 22.73 & -7.13 & 22.10 & -7.13 & - \\
\hline 393 & Seblyavr & Russia & Кухаренко и Донцова, 1962 & 3 & 12.63 & -6.33 & 10.10 & -6.33 & - \\
\hline 398 & Khibiny & Russia & Zaitzev, 1996; Покровский, 2000 & $28^{*}$ & 9.23 & -5.09 & 5.90 & -6.30 & 0.7036 \\
\hline 399 & Ozernaya Varaka & Russia & Самойлов, 1984 & 2 & 12.90 & -7.60 & 11.10 & -7.60 & - \\
\hline 400 & Afrikanda & Russia & Самойлов, 1984 & 4 & 12.35 & -7.55 & 10.30 & -7.55 & - \\
\hline 401 & Lesnaya Varaka & Russia & Кухаренко и Донцова, 1962 & 2 & 11.85 & -6.45 & 10.00 & -6.45 & - \\
\hline 405 & Telyachi Island & Russia & Beard et al., 1996 & $4^{*}$ & 9.12 & -3.76 & 8.80 & -4.23 & - \\
\hline 406 & Turiy Mys & Russia & $\begin{array}{l}\text { Dunworth and Bell, 2001; Demeny et } \\
\text { al., 2004; Владыкин и др., } 2004\end{array}$ & 17 & 7.94 & -2.70 & 7.40 & -2.70 & 0.7033 \\
\hline 407 & Kovdor & Russia & $\begin{array}{l}\text { Плюснин и др., 1980; } \\
\text { Владыкин и др., } 2004\end{array}$ & 7 & 12.10 & -2.30 & 9.40 & -2.30 & 0.7032 \\
\hline 408 & Sallanlatvi & Russia & Demeny et al., 2004 & $4^{*}$ & 14.63 & -1.93 & 10.00 & -3.45 & - \\
\hline 409 & Vuoriyarvi & Russia & $\begin{array}{l}\text { Demeny et al., 2004; } \\
\text { Владыкин и др., } 2004\end{array}$ & 15 & 8.09 & -4.11 & 6.80 & -4.11 & 0.7056 \\
\hline 410 & Tiksheozero & Russia & Щипцов, 1988 & 7 & 11.81 & -5.65 & 10.90 & -5.65 & - \\
\hline 413 & Chetlassky & Russia & $\begin{array}{l}\text { Удоратина и др., 2014; } \\
\text { Шумилова и др., } 2012\end{array}$ & 54 & 11.01 & -3.93 & 8.30 & -3.93 & 0.7034 \\
\hline- & Dubravinsky & Russia & Луговая и др., 2012 & 13 & 10.98 & -5.85 & 8.40 & -5.85 & - \\
\hline 414 & Vishnevogorsky & Russia & Nedosekova et al., 2012, 2013 & $7^{*}$ & 7.53 & -7.10 & 7.00 & -7.67 & 0.7036 \\
\hline 417 & Guli & Russia & Владыкин и др., 2004 & $6^{*}$ & 8.45 & -4.07 & 6.30 & -4.79 & 0.7031 \\
\hline 418 & Odikhincha & Russia & Плюснин и др., 1980 & 2 & 12.60 & -6.40 & 10.00 & -6.40 & 0.7031 \\
\hline 420 & Kugda & Russia & Покровский, 2000 & 2 & 9.9 & -6.4 & 8.7 & -6.4 & 0.7035 \\
\hline- & Potanino & Russia & $\begin{array}{l}\text { Недосекова и др., 2012; } \\
\text { Nedosekova et al., } 2013\end{array}$ & 8 & 8.16 & -6.20 & 7.70 & -6.20 & - \\
\hline- & Buldym & Russia & $\begin{array}{l}\text { Недосекова и др., 2012; } \\
\text { Nedosekova et al., } 2013\end{array}$ & 5 & 8.96 & -7.80 & 8.00 & -7.80 & 0.7044 \\
\hline 426 & Magan & Russia & Кравченко и Багдасаров, 1987 & 2 & 11.40 & -4.60 & 9.90 & -4.60 & - \\
\hline 428 & Essei & Russia & $\begin{array}{c}\text { Кравченко и Багдасаров, 1987; } \\
\text { Владыкин и др., } 2004\end{array}$ & $9^{*}$ & 11.88 & -3.27 & 8.00 & -4.35 & 0.7033 \\
\hline- & East Taimyr & Russia & Proskurnin et al., 2010 & 5 & 11.96 & -4.18 & 6.20 & -4.18 & - \\
\hline 436 & Up. Petropavlovka & Russia & Vrublevskii, 2015 & $10^{*}$ & 13.84 & -2.64 & 11.80 & -3.27 & 0.7057 \\
\hline 437 & Edelveis & Russia & Vrublevskii et al., 2012 & $9^{*}$ & 13.81 & -5.59 & 12.30 & -7.86 & 0.7033 \\
\hline 438 & Tagna & Russia & Владыкин и др., 2004 & 3 & 12.30 & -2.87 & 12.00 & -2.87 & 0.7031 \\
\hline 439 & Nizhnesayansky & Russia & $\begin{array}{l}\text { Doroshkevich et al., 2016; } \\
\text { Владыкин и др., } 2004\end{array}$ & 13 & 6.95 & -5.90 & 6.60 & -5.90 & 0.7029 \\
\hline 440 & Verkhnesayansky & Russia & Владыкин и др., 2004 & $3^{*}$ & 7.10 & -5.57 & 6.80 & -5.49 & 0.7029 \\
\hline 441 & Kharly & Russia & Врублевский, 2003 & 12 & 16.62 & -3.32 & 14.00 & -3.32 & - \\
\hline 443 & Zhidoy & Russia & Morikiyo et al., 2000 & 4 & 7.33 & -5.53 & 7.10 & -5.53 & 0.7030 \\
\hline- & Karasug-calcite & Russia & Nikiforov et al., 2006 & $7^{*}$ & 11.56 & -4.29 & 8.80 & -4.88 & 0.7042 \\
\hline- & Karasug-siderite & Russia & Nikiforov et al., 2006 & 11 & 11.44 & -5.45 & 9.20 & -5.45 & 0.7042 \\
\hline - & Karasug-Teli & Russia & Nikiforov et al., 2006 & 8 & 11.25 & -4.16 & 9.80 & -4.16 & - \\
\hline
\end{tabular}




\section{Continued}

\begin{tabular}{|c|c|c|c|c|c|c|c|c|c|}
\hline- & Karasug-Ulatay & Russia & Nikiforov et al., 2006 & $3^{*}$ & 11.70 & -4.30 & 10.40 & -4.02 & - \\
\hline 445 & Yuzhnoe & Russia & $\begin{array}{l}\text { Никифоров и др., 2000; } \\
\text { Рипп и др., } 2000\end{array}$ & $4^{*}$ & 7.55 & -5.60 & 6.20 & -5.97 & - \\
\hline 446 & Khaluta & Russia & $\begin{array}{l}\text { Никифоров и др., 2000; } \\
\text { Рипп и др., } 2000\end{array}$ & 8 & 12.03 & -6.50 & 9.30 & -6.50 & 0.7057 \\
\hline 448 & Oshurkovo & Russia & $\begin{array}{l}\text { Никифоров и др., 2000; } \\
\text { Рипп и др , 2000, } 2014\end{array}$ & 10 & 10.74 & -6.40 & 7.00 & -6.40 & 0.7053 \\
\hline- & West.Baical-calcite & Russia & Savelyeva et al., 2016 & 4 & 12.70 & -3.98 & 12.50 & -3.98 & 0.7048 \\
\hline- & West.Baical-dolomite & Russia & Savelyeva et al., 2016 & $6^{*}$ & 12.37 & -3.28 & 11.90 & -3.48 & 0.7057 \\
\hline 450 & Veseloe & Russia & $\begin{array}{l}\text { Doroshkevich et al., 2007; } \\
\quad \text { Ласточкин, } 2009\end{array}$ & 10 & 10.16 & -1.59 & 9.10 & -1.59 & - \\
\hline 451 & Pogranichnoe & Russia & Doroshkevich et al., 2006 & 3 & 8.67 & -0.20 & 8.41 & -0.20 & 0.7038 \\
\hline 452 & Murun & Russia & $\begin{array}{l}\text { Владыкин и др., 2004; } \\
\text { Покровский, } 2000\end{array}$ & 20 & 8.42 & -7.36 & 6.0 & -7.36 & 0.7062 \\
\hline 453 & Seligdar & Russia & Doroshkevich et al., 2018 & 5 & 16.48 & -5.36 & 15.90 & -5.36 & 0.7064 \\
\hline 458 & Khani & Russia & Владыкин и др., 2004 & 2 & 8.55 & -8.20 & 8.50 & -8.20 & 0.7045 \\
\hline 459 & Ingili & Russia & Владыкин и др., 2004 & 2 & 8.05 & -6.55 & 8.00 & -6.55 & - \\
\hline 460 & Arbarastakh & Russia & Владыкин и др., 2004 & 3 & 8.27 & -5.07 & 7.60 & -5.07 & - \\
\hline 462 & Koksharovsky & Russia & Октябрьский и др., 2010 & 9 & 11.00 & -5.17 & 9.00 & -5.17 & - \\
\hline 464 & Eppawala & Sri Lanka & $\begin{array}{l}\text { Manthilake et al., 2008; } \\
\text { Pitawala et al., } 2003\end{array}$ & $27^{\star}$ & 14.27 & -2.69 & 7.70 & -3.73 & 0.7049 \\
\hline 467 & Karacayir & Turkey & Cooper et al., 2011 & 2 & 11.39 & -2.34 & 11.28 & -2.34 & 0.7075 \\
\hline 471 & Chagatai & Uzbekistan & $\begin{array}{l}\text { Шумилова и др., 2012; } \\
\text { Лохов и др., } 2007\end{array}$ & $11^{*}$ & 10.06 & -1.71 & 6.50 & -2.59 & - \\
\hline 472 & South Nam Xe & Vietnam & T. Nguyen Thi et al., 2014 & 17 & 9.80 & -3.30 & 9.10 & -3.30 & 0.7082 \\
\hline 476 & Wallaby & Australia & Salier et al., 2004 & 5 & 10.51 & -5.44 & 9.24 & -5.44 & 0.7033 \\
\hline 477 & Mt Weld & Australia & Nelson, 1987 & 2 & 8.05 & -5.50 & 7.20 & -5.50 & 0.7020 \\
\hline 479 & Yungul & Australia & Gwalani et al., 2010 & $37^{\star}$ & 13.84 & -5.69 & 10.40 & -6.20 & - \\
\hline 481 & Cummins Range & Australia & Downes et al., 2014 & $6^{*}$ & 8.28 & -4.10 & 7.50 & -4.17 & - \\
\hline 482 & Mud Tank & Australia & Wilson, 1979 & 4 & 7.50 & -4.13 & 7.50 & -4.13 & 0.7032 \\
\hline 484 & Haast River-calcite & New Zealand & Cooper and Paterson, 2008 & $6^{*}$ & 8.97 & -6.22 & 6.70 & -6.69 & - \\
\hline 484 & Haast River-dolomite & New Zealand & Cooper and Paterson, 2008 & $4^{*}$ & 13.48 & -5.18 & 11.50 & -5.77 & - \\
\hline 488 & Sokli & Finland & Demeny et al., 2004 & $7^{\star}$ & 7.86 & -3.76 & 7.10 & -4.13 & - \\
\hline 489 & Laivajoki & Finland & Nykanen et al., 1997 & $7^{\star}$ & 6.81 & -4.44 & 5.91 & -3.93 & - \\
\hline 490 & Kortejärvi & Finland & Nykanen et al., 1997 & $7^{*}$ & 7.49 & -4.03 & 6.58 & -3.87 & - \\
\hline 492 & Siilinjarvi & Finland & Nykanen et al., 1997 & 6 & 9.22 & -4.07 & 7.40 & -4.07 & - \\
\hline 497 & Laacher See & Germany & Hugh et al., 1966; Jones et al., 2013 & 13 & 7.39 & -6.60 & 6.30 & -6.60 & - \\
\hline 498 & Rockeskyll & Germany & Riley et al., 1999 & $3^{*}$ & 12.40 & -5.07 & 11.10 & -4.94 & 0.7041 \\
\hline 499 & Kaiserstuhl & Germany & $\begin{array}{l}\text { Hubberten, 1988; Dolenek et al., 2015; } \\
\text { Dennis and Schrag, } 2010\end{array}$ & 54 & 9.69 & -5.95 & 5.70 & -5.95 & 0.7036 \\
\hline - & Pelagonian Zone & Greece & Schenker et al., 2018 & 6 & 10.75 & -5.49 & 10.40 & -5.49 & 0.7042 \\
\hline
\end{tabular}


A. V. Bolonin

\section{Continued}

\begin{tabular}{|c|c|c|c|c|c|c|c|c|c|}
\hline- & Mt. Vulture & Italy & Stoppa et al., 2016; Rosatelli et al., 2010 & $4^{*}$ & 10.90 & -4.78 & 10.30 & -4.93 & - \\
\hline 510 & Fen & Norway & $\begin{array}{l}\text { Broom-Fendley et al., 2016; } \\
\text { Andersen, } 1987\end{array}$ & 8 & 6.90 & -4.79 & 5.70 & -4.79 & 0.7021 \\
\hline 515 & Alnö & Sweden & $\begin{array}{c}\text { Roopnarain, 2013; Hugh et al., 1966; } \\
\text { Jones et al., } 2013\end{array}$ & 29 & 7.71 & -5.53 & 6.40 & -5.53 & 0.7029 \\
\hline 518 & Chernigovsky & Ukraine & Луговая и др., 1978 & 11 & 8.49 & -5.77 & 5.30 & -5.77 & 0.7013 \\
\hline 519 & Loch Borralan & UK Scotland & Young et al., 1994 & 2 & 10.36 & -5.02 & 10.32 & -5.02 & - \\
\hline 520 & Fuerteventura & Spain & $\begin{array}{l}\text { Hoernle et al., 2002; } \\
\text { Шумилова и др., } 2012\end{array}$ & 12 & 7.32 & -5.72 & 6.60 & -5.72 & - \\
\hline 522 & Sao Vicente & Cape Verdes & Hoernle et al., 2002 & 2 & 7.85 & -4.80 & 7.30 & -4.80 & 0.7031 \\
\hline 524 & Fogo & Cape Verdes & Hoernle et al., 2002 & $4^{*}$ & 6.58 & -6.70 & 5.30 & -7.09 & 0.7031 \\
\hline
\end{tabular}

